Hoffmann La Roche, Basel

\title{
Experimental Studies with Methylhydrazine Derivatives
}

\section{W. Bollag}

Methylhydrazine compounds constitute a new class of antitumour substances whose mechanism of action appears to be different from that of other cytotoxic agents.

Among a large series of hydrazines and hydrazides which have been synthesized in search of monoamine oxidase inhibitors, the first derivative found to possess a certain antitumour activity was I-methyl-2-benzyl-hydrazine (Bollag and Grunberg, 1963):

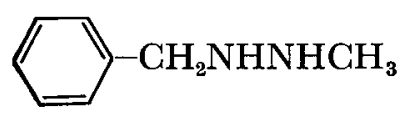

This compound which showed pronounced inhibition of several transplantable tumours in mice and rats had, however, a low therapeutic index and, furthermore, caused liver damage.

Zeller et al. (1963), therefore, synthesized a large series of hydrazines in order to obtain a compound with better chemotherapeutic activity and lower toxicity. The systematic variation of the molecule revealed that active representatives of this chemical group were only found among compounds of the general formula:

$$
\mathrm{R}-\mathrm{CH}_{2} \mathrm{NHNHCH}_{3}
$$

The biological properties within this group showed a marked variation depending on the chemical structure of the radical $\mathrm{R}$.

\section{Effect on transplantable tumours}

The methylhydrazine compounds were systematically tested on the following transplantable tumours: Ehrlich carcinoma, solid form, Ehrlich carcinoma, ascitic form and Crocker sarcoma S I8o in mice; Walker carcinosarcoma 256 and uterus epithelioma (Guérin) T8 in rats. The growth of these tumours is markedly influenced by many methylhydrazine derivatives. Among these, Ro $4-6467 / \mathrm{I}=\mathrm{p}-\left(\mathrm{N}^{1}-\right.$ methylhydrazinomethyl)-N-isopropyl benzamide hydrochloride or Natulan (Bollag, I963, I964) exhibited a particularly favourable therapeutic index. 


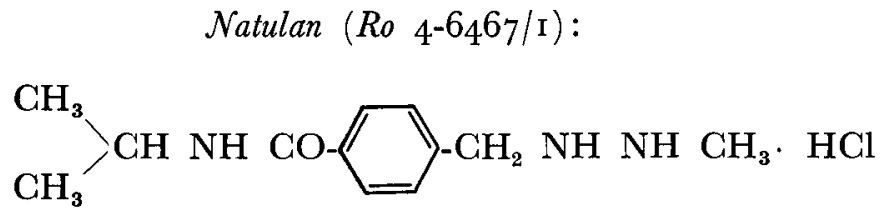

Tables I-4 show the inhibitory activity of Natulan on Ehrlich carcinoma, solid form, Ehrlich carcinoma, ascitic form, Walker carcinosarcoma 256 , and uterus epithelioma (Guérin) T8.

Tab. 1. Ehrlich carcinoma, solid form

Natulan i.p., 5 times within seven days

\begin{tabular}{c|c|c|c}
\hline $\begin{array}{c}\text { Natulan } \\
\text { daily dose } \\
(\mathrm{mg} / \mathrm{kg})\end{array}$ & $\begin{array}{c}\text { Tumour } \\
\text { weight } \\
(\mathrm{mg})\end{array}$ & $\begin{array}{c}\text { Weight } \\
\text { change } \\
\text { of mice }(\mathrm{g})\end{array}$ & $\begin{array}{c}\text { Tumour } \\
\text { inhibition } \\
(\%)\end{array}$ \\
\hline Controls & $5^{29}$ & $+\mathrm{r} .2$ & 0 \\
I00 & $\mathrm{I}^{8}$ & +0.2 & 70.2 \\
200 & 50 & -2.2 & 90.6 \\
300 & 40 & -2.8 & 92.5 \\
400 & 37 & -4.3 & 93.0
\end{tabular}

Tab. 2. Ehrlich ascites carcinoma

Natulan j.p., 7 times within 9 days

\begin{tabular}{c|c|c}
\hline $\begin{array}{c}\text { Natulan } \\
\text { daily dose } \\
(\mathrm{mg} / \mathrm{kg})\end{array}$ & $\begin{array}{c}\text { Survival } \\
\text { time } \\
\text { (days) }\end{array}$ & $\begin{array}{c}\text { Prolongation } \\
\text { of life } \\
(\%)\end{array}$ \\
\hline Controls & 10.2 & 0 \\
100 & 18.6 & 80 \\
200 & 23.4 & 130 \\
300 & 42.2 & 310 \\
400 & 40.8 & 300
\end{tabular}

Tab. 3. Walker carcinosarcoma 256

Natulan i.p., 6 times within 8 days

\begin{tabular}{c|c|c|c}
\hline $\begin{array}{c}\text { Natulan } \\
\text { daily dose } \\
(\mathrm{mg} / \mathrm{kg})\end{array}$ & $\begin{array}{c}\text { Tumour } \\
\text { weight } \\
(\mathrm{mg})\end{array}$ & $\begin{array}{c}\text { Weight } \\
\text { change } \\
\text { of rats }(\mathrm{g})\end{array}$ & $\begin{array}{c}\text { Tumour } \\
\text { inhibition } \\
(\%)\end{array}$ \\
\hline Controls & 4905 & +22.6 & 0 \\
$j$ & 954 & +23.0 & 80.6 \\
I0 & 0 & +20.7 & 100 \\
20 & 0 & +12.8 & 100 \\
30 & 0 & +7.8 & 100
\end{tabular}


Acta Geneticae Medicae et Gemellologiae

Tab. 4. Uterus epithelioma (Guérin) T8

Natulan i.p., 6 times within 8 days

\begin{tabular}{c|c|c|c}
\hline \hline $\begin{array}{c}\text { Natulan } \\
\text { daily dose } \\
(\mathrm{mg} / \mathrm{kg})\end{array}$ & $\begin{array}{c}\text { Tumour } \\
\text { weight } \\
(\mathrm{mg})\end{array}$ & $\begin{array}{c}\text { Weight } \\
\text { change } \\
\text { of rats }(\mathrm{g})\end{array}$ & $\begin{array}{c}\text { Tumour } \\
\text { inhibition } \\
(\%)\end{array}$ \\
\hline Controls & 22496 & +10.6 & 0 \\
2.5 & 6908 & +31.0 & 69.3 \\
5 & $426 \mathrm{I}$ & +22.4 & $81 . \mathbf{1}$ \\
I0 & 0 & +6.2 & I00
\end{tabular}

Natulan exerts a particularly marked inhibition on transplantable tumours in rats. In experiments with treatment beginning on the day after implantation, the growth of the Walker carcinosarcoma and of the uterus epithelioma T8 was completely suppressed by non-toxic doses. Natulan is not only effective when treatment has begun before the take of the tumour, it also exerts a therapeutic effect on well established tumours. If treatment of Walker tumours has begun as late as 5 days after implantation, i.e. when the tumour has already reached the size of an almond, a regression can be obtained. The regression of such tumours can be followed by histological examination.

Figs. I and 2 show that after treatment with Natulan the number of tumour cells already decreases markedly during the first 3 days. The tumour tissue is replaced by inflammatory tissue and finally by fibrous tissue.

In some of the animals this regression is complete and no recurrence is observed within a period of roo days. However, in other animals, although regression to almost non palpable nodules is obtained, this is only temporary, as tumour growth reappears in spite of continued treatment.

With the Walker carcinosarcoma, drug resistance can develop within the same generation, whereas with Ehrlich carcinoma drug resistance could be observed only after continued treatment of 7 to 9 generations of inoculated mice.

\section{Effect of Natulan on other rapidly proliferating tissues}

Like all other antitumour agents, Natulan does not act selectively on tumour tissue. Other rapidly proliferating tissues such as the haemopoietic tissues, the germinal epithelium and the hair follicles are also affected (Bollag and Theiss, 1964).

Natulan exerts a considerable effect on haemopoiesis. All blood-forming systems are affected. Leukopoiesis and thrombopoiesis are markedly damaged while the erythropoiesis is influenced much less. Both lines of white blood cells, the myeloid and the lymphoid series, are depressed by Natulan. Depending on the species used, the influence on leukopoiesis varies considerably. Thus Natulan predominantly depresses the granulopoiesis in dogs, while in rats it mainly affects the lymphopoiesis. 


\section{Walker tumour control}

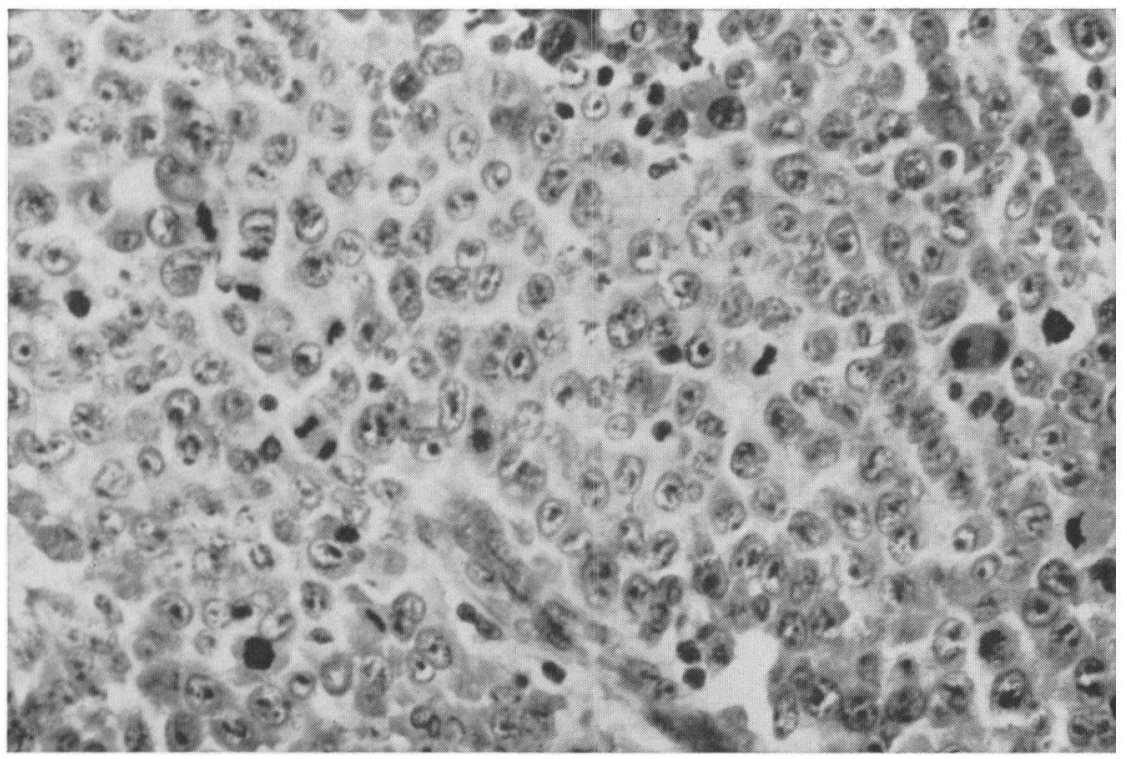

Fig. 1. Histological section of the peripheral zone of a Walker tumour, 8 days after implantation. The tumour tissue is in full proliferation. Many cells in mitosis. (Hematoxylin-eosin, magnification $\times 400$ )

\section{Walker tumour \\ after 3 days' treatment with Natulan}

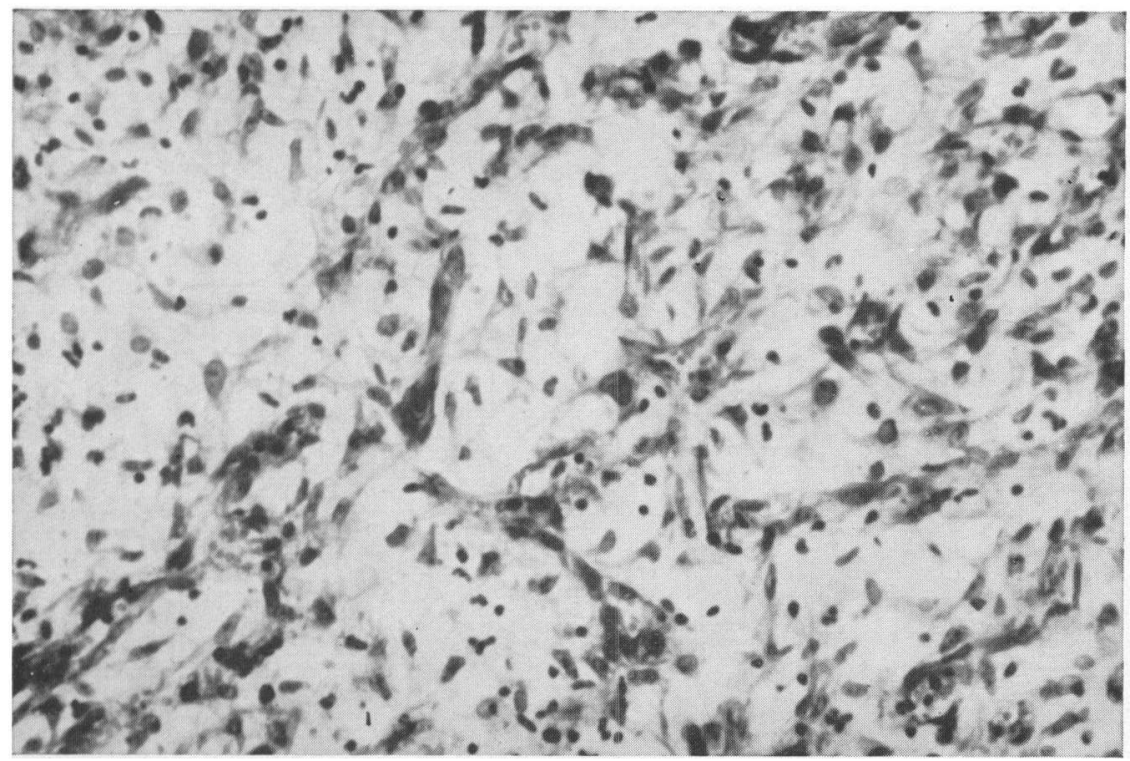

Fig. 2. Histological section of the peripheral zone of a Walker tumour, 8 days after implantation. Due to treatment, the tumour cells have almost disappeared. Replacement of the tumour tissue by granulation tissue and fibrous tissue. (Hematoxylin-eosin, magnification $\times 400$ ) 
Tab. 5 shows the effect of Natulan on the leukopoiesis in rats.

Tab. 5. Leukopoiesis in the rat

\begin{tabular}{|c|c|c|c|c|c|}
\hline \multicolumn{6}{|c|}{ Natulan } \\
\hline Dose & & $\begin{array}{l}\text { Initial } \\
\text { values }\end{array}$ & $\begin{array}{c}\text { After } \\
2 \text { weeks }\end{array}$ & $\begin{array}{c}\text { After } \\
4 \text { weeks }\end{array}$ & $\begin{array}{c}\text { After } \\
6 \text { weeks }\end{array}$ \\
\hline \multirow{4}{*}{$\begin{array}{l}20 \mathrm{mg} / \mathrm{kg} \\
\text { per day }\end{array}$} & leukocytes & 10500 & 8300 & 4700 & 2700 \\
\hline & Iymphocytes & 7830 & 6600 & $3^{190}$ & $174^{\circ}$ \\
\hline & neutrophils & 2520 & 1520 & 1360 & 860 \\
\hline & & $\begin{array}{l}\text { Initial } \\
\text { values }\end{array}$ & $\begin{array}{c}\text { After } \\
2 \text { weeks }\end{array}$ & $\begin{array}{c}\text { After } \\
4 \text { weeks }\end{array}$ & $\begin{array}{c}\text { After } \\
6 \text { weeks }\end{array}$ \\
\hline \multirow{4}{*}{$\begin{array}{l}70 \mathrm{mg} / \mathrm{kg} \\
\text { per day }\end{array}$} & leukocytes & 10500 & 3100 & I 800 & 1400 \\
\hline & lymphocytes & 7830 & 2030 & 8 Io & 420 \\
\hline & neutrophils & 2520 & 1020 & $94^{\circ}$ & 940 \\
\hline & & $\begin{array}{l}\text { Initial } \\
\text { values }\end{array}$ & $\begin{array}{l}\text { After } \\
2 \text { days }\end{array}$ & $\begin{array}{c}\text { After } \\
4 \text { days }\end{array}$ & $\begin{array}{l}\text { After } \\
6 \text { days }\end{array}$ \\
\hline \multirow{3}{*}{$\begin{array}{l}200 \mathrm{mg} / \mathrm{kg} \\
\text { per day }\end{array}$} & leukocytes & 10500 & 3300 & 1800 & 700 \\
\hline & lymphocytes & 7830 & 2400 & $105^{\circ}$ & 310 \\
\hline & neutrophils & $25^{20}$ & 880 & $7^{80}$ & $3^{80}$ \\
\hline
\end{tabular}

Haemolysis is a manifestation of toxicity common to many hydrazine derivatives. It is due to the formation of methaemoglobin and the appearance of Heinz-Ehrlich inclusion bodies in the erythrocytes. As a consequence of haemolysis, reticulocytosis and storage of haemosiderin in various organs are observed.

\section{Mechanism of action of methylhydrazine derivatives}

\section{Gytologigal studies}

\section{A. Ehrlich ascites carcinoma}

Cytological studies revealed that the substances belonging to the group of methylhydrazine derivatives exert a marked influence on the mitotic cycle (Rutishauser and Bollag, 1963). The experiments were carried out on Ehrlich ascites carcinoma. The tumour used has a rather stable chromosomal variation pattern with a stemline chromosome number of 66 . This hypertriploid tumour with 2 metacentric marker chromosomes showed no spontaneous chromosome or chromatid breaks. 
I. Mitotic index

Under the influence of methylbenzylhydrazine (MBH) the mitotic index decreases very markedly. The mitotic index in the non-treated controls varies between $5.3 \%$ and $9 \%$. In the treated animals, depending on the dose of the cytotoxic agent and the lapse of time after its administration, the index falls to a minimum of 0.5 to $0.6 \%$, i.e. to about $\mathrm{r} / \mathrm{Io}$ of the control values (Tab. 6).

Tab. 6. Mitotic index

\begin{tabular}{l|c|c}
\hline Dose & $\begin{array}{c}\text { Hrs after single } \\
\text { injection }\end{array}$ & $\begin{array}{c}\text { Mitotic index } \\
\text { in \% }\end{array}$ \\
\hline Controls & 8 & 9 \\
& 24 & 8.4 \\
& $4^{8}$ & $5 \cdot 3$ \\
$200 \mathrm{mg} / \mathrm{kg}$ & $7^{2}$ & 6.4 \\
MBH i.p. & 8 & 0.6 \\
& 24 & $5 \cdot 4$ \\
$300 \mathrm{mg} / \mathrm{kg}$ & $4^{8}$ & $3 \cdot 4$ \\
MBH i.p. & 72 & $5 \cdot 5$ \\
& 24 & 0.8 \\
& 48 & 0.5
\end{tabular}

\section{Phase ratio}

The analysis of the different phases of the mitotic cycle shows a slight shift from prophase to metaphase. The percentage of ana- and telophases does not change significantly.

\section{Chromosome number}

The number of chromosomes in our hypertriploid ascites tumour with its stemline number (S) of 66 does not show any alteration in its chromosome variation pattern under the influence of $\mathrm{MBH}$.

\section{Chromosomal aberrations}

After the treatment with methylhydrazine derivatives a high number of chromosomal aberrations occurs. A few free chromatid breaks can be observed, however interchange and triradial recombinations prevail by far (Fig. 3). 


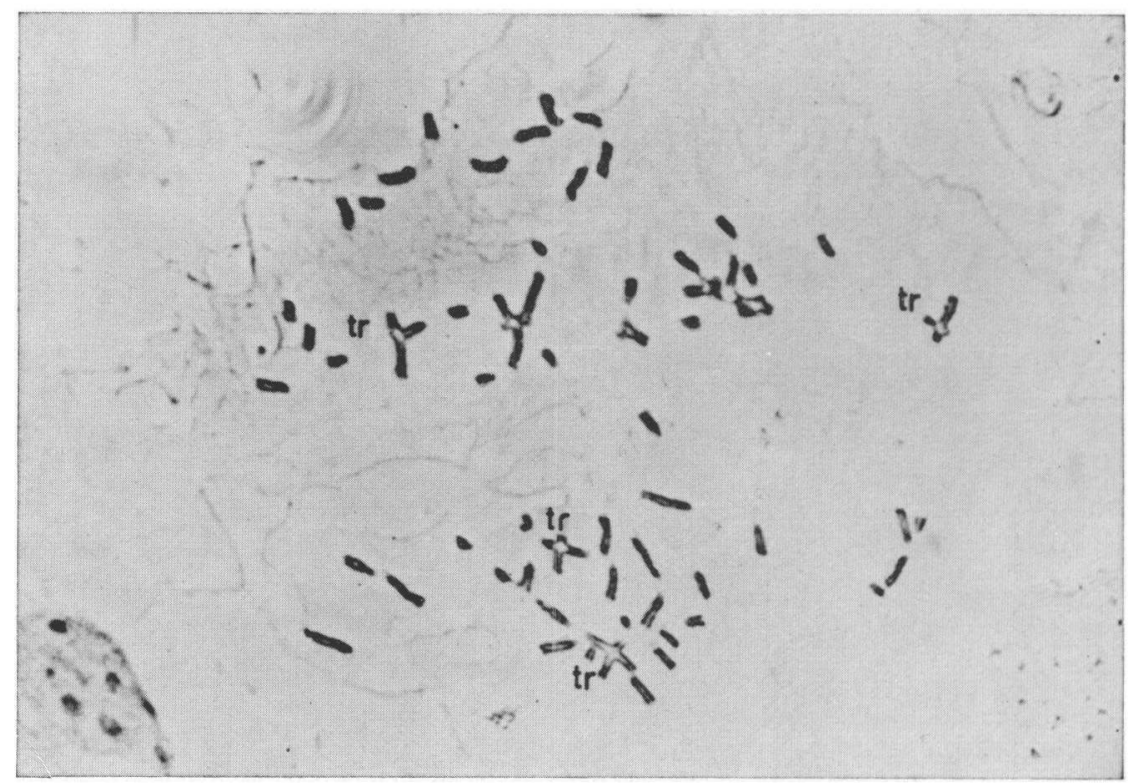

Fig. 3. Metaphase plate, $4^{8} \mathrm{hrs}$ after $400 \mathrm{mg} / \mathrm{kg} \mathrm{MBH}$. Chromosomal aberrations, in which some of the recombinations are pointed out as $\operatorname{tr}=$ translocation (interchange)

The number of breaks depends on the dose of the drug and the lapse of time after the injection of methylhydrazine derivatives. In the next Tab. 7 the mean percentage of chromatid breaks is indicated. $1 \%$ breaks mean that in one of 100 investigated metaphase plates one chromatid break is found. In our calculation an interchange form is counted e.g. as 4 , as this recombination is the consequence of 4 chromatid breaks.

Tab. 7. Chromatid breaks

\begin{tabular}{l|c|c}
\hline Dose & $\begin{array}{c}\text { Hrs after single } \\
\text { injection }\end{array}$ & $\begin{array}{c}\text { Mean percentage } \\
\text { of breaks }\end{array}$ \\
\hline Controls & & 0 \\
$200 \mathrm{mg} / \mathrm{kg}$ & 8 & 0 \\
$\mathrm{MBH}$ i.p. & 24 & 3.3 \\
& 48 & 38.0 \\
$400 \mathrm{mg} / \mathrm{kg}$ & 72 & 29.0 \\
$\mathrm{MBH}$ i.p. & 48 & 70.4 \\
& 72 & 280.0 \\
& 168 & 255.6 \\
& 192 & 39.6
\end{tabular}


From these results the following conclusions were drawn:

The low mitotic index is interpreted as a suppression of mitosis brought about by a prolongation of the interphase. As the slight shift in distribution from prophase to metaphase is not followed by a decrease of ana- and telophase and is furthermore combined with a low mitotic index, a colchicine-like effect can be excluded. The chromosomal aberrations induced by the methylhydrazine derivatives show a specific pattern. Only chromatid breaks and chromatid reunions but no chromosome breakage could be observed. From this fact it may be inferred that the breaks are induced during or after deoxyribonucleic acid synthesis, i.e. either in the $\mathrm{S}$ or the $\mathrm{G}_{2}$ phase. Under the treatment with methylhydrazine derivatives there is no change in the chromosome number. This may imply that the cells presenting chromosomal aberrations are no more viable and do not survive the next cycle.

\section{B. Tissue culture}

The effect of methylhydrazine derivatives on tissue culture has been examined by several authors (Mosimann, Staiger, Rutishauser). In contrast to the definite effect of Natulan on mitosis and chromosomes in vivo, its influence on cells in tissue culture is very weak. A certain inhibitory effect on the growth of tissue cultures of Hela- and KB-cells has been seen, but only with the high doses of 100 to $1000 \mathrm{\gamma} / \mathrm{ml}$ medium. Primary rat kidney tissue cultures and tissue cultures of the human carcinoma HEP 2 were hardly inhibited in their growth by Natulan. In primary rat kidney tissue culture $2000 \mathrm{\gamma} / \mathrm{ml}$ did not induce any chromosomal aberrations. The enormous dose of $4000 \mathrm{r} / \mathrm{ml}$ did not interfere with the growth of HEP 2 cultures and induced only a very few chromosome breaks, however no chromatid breaks and no reunions. This discrepancy between the results in vitro and in vivo may be explained by the hypothesis that only a metabolite of Natulan exerts the cytotoxic effect. The azoderivative of Natulan, the only metabolite known to be effective in tumour inhibition experiments in vivo has been examined but has been found inactive in tissue culture. Thus we do not yet know the reason for the almost complete inactivity of Natulan in vitro.

\section{Autoradiographic studies}

The above-mentioned studies had revealed that the sensitive period of the cell is either the $S$ or $G_{2}$ period of the interphase. Further investigations were carried out on Ehrlich ascites carcinoma cells for obtaining information on the effect of Natulan on the DNA synthesis (Rutishauser and Bollag, I967). We measured the incorporation of $\mathrm{H}^{3}$-thymidine in the DNA of the nucleus by autoradiography. $\mathrm{H}^{3}$-thymidine in a dose of го $\mu \mathrm{c}$ was administered to ascites tumour bearing mice. Ascites was taken Io hrs after injection of $\mathrm{H}^{3}$-thymidine. Natulan was given at different intervals 
before the administration of $\mathrm{H}^{3}$-thymidine. From Tab. 8 it can be seen that Natulan has a marked effect on the incorporation of $\mathrm{H}^{3}$-thymidine into DNA.

Tab. 8. Effect of Natulan on thymidine incorporation (autoradiography of Ehrlich ascites carcinoma cells)

\begin{tabular}{|c|c|c|c|}
\hline \multirow{2}{*}{ Treatment } & \multicolumn{3}{|c|}{$\begin{array}{l}\text { Number of silver grains } \\
\text { to hrs after } \mathrm{H}^{3} \text {-thymidine injection }\end{array}$} \\
\hline & $\begin{array}{l}\text { Maximal value } \\
\text { per nucleus }\end{array}$ & $\begin{array}{l}\text { Mean value } \\
\text { of all nuclei }\end{array}$ & $\begin{array}{l}\text { Mean value } \\
\text { of active nuclei }\end{array}$ \\
\hline $\mathrm{H}^{3}$-thymidine so $\mu \mathrm{c}$ & 92 & I 1.3 & 17.2 \\
\hline $\begin{array}{l}200 \mathrm{mg} / \mathrm{kg} \text { Natulan } 8 \mathrm{hrs} \\
\text { before } \mathrm{H}^{3} \text {-thymidine Io } \mu \mathrm{c}\end{array}$ & 45 & 4.8 & 7.9 \\
\hline $\begin{array}{l}200 \mathrm{mg} / \mathrm{kg} \text { Natulan } 72 \mathrm{hrs} \\
\text { before } \mathrm{H}^{3} \text {-thymidine ro } \mu \mathrm{c}\end{array}$ & $4^{6}$ & $3 \cdot 1$ & 6.7 \\
\hline
\end{tabular}

When Natulan was given $72 \mathrm{hrs}$ before $\mathrm{H}^{3}$-thymidine the number of silver grains in the area of the nucleus decreased from II.3 to $3 . \mathrm{I}$ if we count all nuclei, or from I 7.2 to 6.7 if we count only the active nuclei. These latter nuclei undergoing the synthesizing period of the interphase constitute about $60 \%$ of all nuclei. Furthermore the highest number of silver grains in the controls amounts to $9^{2}$ per nucleus, whereas the nuclei of Natulan treated animals reach only values of 46 per nucleus. From these results the conclusion can be drawn that the DNA synthesis is markedly inhibited, the percentage of inhibition ranging between $5^{\circ}$ and $70 \%$.

These results are in good agreement with findings of other authors, who observed with other methods and on other tissues a marked inhibition of DNA synthesis by Natulan (Fölsch et al., rg64; Weitzel; Trepel et al.).

\section{Biochemical AND PHysioghemical stUdies}

We have just dealt with the inhibition of the synthesis of DNA by Natulan, which may be one of the possible mechanisms responsible for the cytotoxic activity. Many more factors may play a decisive role. Thus not only the deoxyribonucleic acid synthesis but also the ribonucleic acid synthesis is inhibited (Weitzel; Trepel et al., 1966). Furthermore it has been established that Natulan interferes markedly with protein synthesis (Fölsch et al., i964; Koblet).

Since the influence on the chromosomes is probably focussed on their main constituent which is the deoxyribonucleic acid, in vitro studies have been performed with the latter (Berneis et al., I963, I964; Brookes, I965). It is well known that the influence of radiation and alkylating agents cause the degradation of DNA whereby it is split into smaller fragments. The methylhydrazine derivatives likewise act by fragmentation of DNA but unlike nitrogen mustards only in the presence of oxygen. 
Under Natulan treatment DNA remains intact in a nitrogen medium. These effects measured by the viscosity of aqueous DNA or by determining its molecular weight, are due to autoxidation of the methylhydrazine derivatives leading to the formation of hydrogen peroxide or $\mathrm{OH}$ radicals. The degradation of DNA in oxygen medium can be inhibited by addition of catalase (Fig. 4).

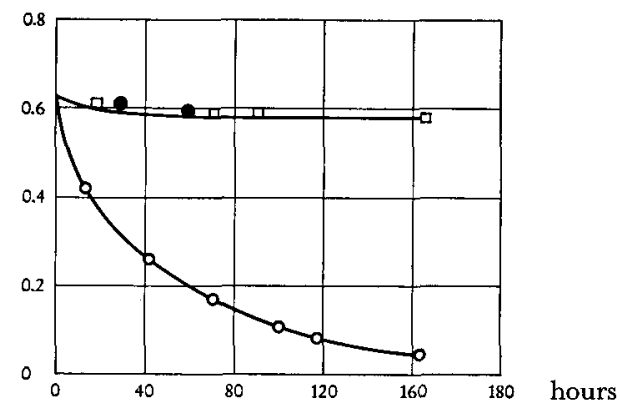

Fig. 4. Changes in the specific viscosity of a $0.07 \%$ DNA solution containing $0.0005 \mathrm{~mol} / \mathrm{l} \mathrm{Natulan}$

$$
\begin{aligned}
& O=\text { in air } \\
& \square=\text { in air with addition of catalase }
\end{aligned}
$$

By other experiments it could be proven that the methylhydrazine derivatives promote reactions between peroxidic radicals and organic compounds such as for instance the deoxyribose (Berneis et al., 1964).

The depolymerizing effect on DNA could not yet be confirmed in experiments in vivo (Koblet). However the methods available for such a proof may not be adequate for discovering minor differences in weight and shape of DNA molecules.

Natulan may also act by an alkylating mechanism. Brookes (I965) demonstrated, by using $\mathrm{H}^{3}$-labelled Natulan, that a methyl group of Natulan is transferred to the guanine part of DNA, thus methylating guanine to 7-methylguanine. This alkylation could be achieved only in vivo in the Ehrlich ascites carcinoma, but - unlike the nitrogen mustards - not in vitro, in the test tube or in tissue culture. Kreis et al. (I966) found in the urine of mice bearing Leukemia P 8I 5 treated with $\mathrm{C}^{14}$-labelled Natulan not only large quantities of 7 -methylguanine but in addition 1 -methyladenine and I-methylhypoxanthine.

The methylation of the purine bases of DNA (guanine and adenine) may change the genetic code of the cells and disturb in this way the reduplication of DNA and the synthesis of RNA and proteins necessary for growth. Many more investigations point to the fact that the mechanism of action of methylhydrazine derivatives differs from that of other cytotoxic agents (Weitzel et al., ig64; Obrecht et al., 1964).

In summarising it may be said that the methylhydrazine derivatives are known to possess a marked influence on preexisting DNA, as well as on the synthesis of DNA, 
RNA and proteins, but that we ignore the exact mechanism responsible for the cytotoxic effect. Anyhow the mechanism of action must be different from that of other antitumour agents, as there does not exist a cross-resistance between Natulan and any compound of another class of cytotoxic agents.

\section{Summary}

Natulan (Procarbazine) is a methylhydrazine derivative which in animal experiments inhibits a series of transplantable tumours. The Walker carcinoma is markedly affected. Even well established Walker tumours disappear completely under Natulan treatment. Tumour tissue is replaced by fibrous tissue. Natulan does not act selectively on neoplastic tissue, it also depresses the growth of other rapidly proliferating tissues such as the bone marrow.

As regards the mechanism of action the following data are known: Natulan lowers the mitotic index by prolonging the interphase and hindering the cell from entering into mitosis. In Ehrlich ascites tumour cells chromatid breaks were observed. Natulan depolymerizes deoxyribonucleic acid (DNA) in vitro. In vivo the synthesis of DNA is inhibited. Furthermore alkylation of purine bases has been demonstrated. All these mechanisms may be responsible for the cytotoxic effect of methylhydrazine derivatives. Natulan does not possess cross-resistance towards other cytotoxic agents. This phenomenon is a further proof of its particular mechanism of action.

\section{References}

BerneIs K. et al. (1963). Der pro-oxydative Effekt tumorhemmender Methylhydrazin-Verbindungen. Helv. Chim. Acta, 46: 2 I57-2 167.

- - (1963). The degradation of deoxyribonucleic acid by new tumor inhibiting compounds: the intermediate formation of hydrogen peroxide. Experientia, 19: 132-133.

- - (I964). Die Auslösung von Fenton-Reaktionen durch cytotoxische Methylhydrazin-Verbindungen. Helv. Chim. Acta, 47: 1903-191 I.

Bollag W. (1963). The tumor-inhibitory effects of the methylhydrazine derivative Ro 4-6467/I (NSG-77213). Cancer Chemother. Rep., 33: 1-4.

- (1964). Investigations with methylhydrazine derivatives. In: Chemotherapy of Cancer. Ed. Plattner. Elsevier, Amsterdam, London, New York, I9I-I97.

- Grunberg E. ( 1963 ). Tumor inhibitory effects of a new class of cytotoxic agents: methylhydrazine derivatives. Experientia, 19: 130-131.

- Theiss E. (1964). Selective toxicity of antitumor agents: methylhydrazine derivatives. In: Chemotherapy of Cancer. Ed. Plattner. Elsevier, Amsterdam, London, New York, 311-313.

Brookes P. (1965). Studies on the mode of action of ibenzmethyzine. In: Natulan. Ed. Jelliffe and Marks. Wright \& Sons, Bristol, 9-12.

FöLsch E. et al. (1964). Ủber die Wirkung eines neuen Cytostaticums (Ro 4-6467) auf den Einbau markierten Glycins in Tumorzellen. Verh. Deutsch. Ges. Inn. Med., 70: 995-998.

Koblet H. Personal Communication.

Kreis W. et al. (ig66). Studies on the metabolic fate of the Cr4-labelled methyl group of a methylhydrazine derivative in P 815 mouse leukemia. Experientia, 22: $43 \mathrm{I}-433$. 
Mosimann W. Personal Communication.

Obrecht P. et al. (1964). Zur Frage der biochemischen-Wirkung eines neuen Cytostaticums, Ro 4-6467, aus der Klasse der Methylhydrazinderivate. Chemotherapia, 8: 106-113.

Rutishauser A. Personal Communication.

- Bollag W. (1963). Cytological investigations with a new class of cytotoxic agents: methylhydrazine derivatives. Experientia, 19: 131-132.

- - (1967). Untersuchungen über den Wirkungsmechanismus von Procarbazin (Natulan). Experientia, 23: 222-223.

Staiger G. R. Personal Communication.

Trepre F. et al. (1966). Nukleinsäuresynthese und Zytostaticawirkung in pathologischen Lymphknotenzellen. Med. Klin., 61: 618-622.

Weitzel G. Personal Communication.

- et al. (1964). Cytostatischer Wirkungsmechanismus der Methylhydrazine. Experientia, 20: ${ }_{3}^{8-39}$.

Zelder P. et al. (1963). Methylhydrazine derivatives, a new class of cytotoxic agents. Experientia, 19: 129.

\section{RIASSUNTO}

Il Natulan (Procarbazina) è un derivato della metilidrazina, che presenta una notevole azione inibitrice su di una serie di tumori trapiantabili nell'animale. Fortemente influenzato è in particolare il tumore di Walker nel ratto. Anche se ben radicati, i carcinomi di Walker possono scomparire completamente dopo trattamento con Natulan, in quanto il tessuto tumorale viene ad essere sostituito da tessuto connettivo. Il Natulan non danneggia soltanto il tessuto neoplastico, ma anche altri tessuti a rapida proliferazione, come ad esempio il midollo osseo. Per quanto riguarda il meccanismo d'azione è stato osservato quanto segue: il Natulan abbassa l'indice mitotico, prolungando l'interfase ed impedendo in tal modo alla cellula di entrare in mitosi. Nel caso del carcinoma ascitico di Ehrlich sono state osservate rotture cromatidiche. In vitro il Natulan depolimerizza l'ADN. In vivo, la sintesi dell'ADN viene impedita ed è stata dimostrata la alchilazione delle basi puriniche. Tutti questi meccanismi possono essere responsabili dell'effetto citostatico del Natulan. D'altra parte, non esiste resistenza crociata fra Natulan e altri agenti citostatici, il che dimostra che il Natulan possiede il suo proprio meccanismo d'azione.

\section{RÉSUMÉ}

Le Natulan (Procarbazine) est un dérivé de la méthylhydrazine, qui montre une action inhibitrice marquée sur une série de tumeurs transplantables chez l'animal. Particulièrement la tumeur de Walker du rat est fortement influencée. Même des carcinomes de Walker bien établis peuvent disparaître complètement sous traitement au Natulan, le tissu tumoral étant remplacé par du tissu conjonctif. Le Natulan n'endommage pas seulement le tissu néoplasique mais aussi d'autres tissus à prolifération rapide comme par exemple la moëlle osseuse. En ce qui concerne le mécanisme d'action, les faits suivants ont été notés: le Natulan abaisse l'index mitotique, en prolongeant l'interphase, empêchant de ce fait la cellule d'entrer en mitose. Dans le cas du carcinome ascitique d'Ehrlich, des ruptures de chromatides ont été observées. In vitro, le Natulan dépolymérise l'acide désoxyribonucléique $(A D N)$. In vivo, la synthèse de l'ADN est inhibée et l'alchylation de bases puriniques a été démontrée. Tous ces mécanismes peuvent être responsables de l'effet cytostatique du Natulan. D'autre part, il n'existe pas de résistance croisée entre le Natulan et d'autres agents cytostatiques, ce qui démontre que le Natulan possède son propre mécanisme d'action. 


\section{ZUSAMMENFASSUNG}

Natulan (Procarbazin) ist eine Methylhydrazinverbindung, die im Tierversuch eine deutliche Hemmwirkung auf eine Reihe von transplantablen Geschwülsten zeigt. Der Walker-Tumor der Ratte wird besonders stark beeinflusst. Auch bereits etablierte Walker-Karzinome können noch vollständig zur Rückbildung gebracht werden, wobei das Tumorgewebe durch Narbengewebe ersetzt wird. Natulan schädigt nicht nur neoplastisches Gewebe, sondern auch andere rasch proliferierende Gewebe wie z.B. das Knochenmark. Utber den Wirkungsmechanismus sind folgende Daten bekannt: Natulan senkt den Mitoseindex, indem es die Interphase verlängert und dadurch die Zelle am Eintritt in die Mitose hindert. Chromatidbrüche wurden an den Zellen des EhrlichAszites-Karzinoms beobachtet. Natulan depolymerisiert in vitro die Desoxyribonukleinsäure (DNS). In vivo wird die Synthese von DNS gehemmt. Es kommt ferner zu einer Alkylierung von Purinbasen. Alle diese Mechanismen können für die cytostatische Wirkung von Natulan verantwortlich sein. Natulan besitzt keine Kreuzresistenz gegenüber anderen Cytostatica. Dieses Phänomen ist ein weiterer Hinweis dafür, dass Natulan einen besonderen Wirkungsmechanismus aufweist. 